\title{
Inhibition of growth and secreted aspartyl proteinase production in Candida albicans by lysozyme
}

\author{
T. WU* $\$$, L. P. SAMARANAYAKE*,$W . K$. LEUNG* and P. A. SULLIVAN $\dagger$ \\ * Faculty of Dentistry. University of Hong Kong, Hong Kong and †Department of Biochemistry, Massey \\ University, Palmerston North, New Zealand
}

\begin{abstract}
Lysozyme (muramidase) is a non-specific, antimicrobial protein ubiquitous in human mucosal secretions such as saliva. Although its antibacterial and antifungal activities are well recognised, there are no data on the specific concentrations necessary to affect the growth of Candida albicans or about the effect of lysozyme on the production of secreted aspartyl proteinase (Sap), a putative virulence factor of $C$. albicans. Five Sap-producing isolates of $C$. albicans were cultured in YCB-BSA medium with various concentrations of lysozyme to examine its effect on yeast cell growth, ultrastructural cellular topography and extracellular and intracellular Sap concentration and activity. Lysozyme was candidacidal at high concentrations and decreased significantly the extracellular Sap concentration at sublethal doses, accompanied by intracellular accumulation of the enzyme. At low concentrations of lysozyme $(c .10 \mu \mathrm{g} / \mathrm{ml})$, Sap activity decreased more than two-fold and Sap concentration decreased five-fold without any appreciable effect on cell growth or viability. Ultrastructural investigations showed ballooned cells and cells with invaginations (expecially present near bud scars), indicating that cell-wall components may be possible targets for this enzyme. All concentrations of lysozyme tested were well within physiologically attainable levels. These data suggest that lysozyme has, at least, a bimodal action on $C$. albicans, killing the organism at higher concentrations and modulating Sap metabolism at lower concentrations.
\end{abstract}

\section{Introduction}

Candida albicans, a common inhabitant of the human oral cavity, is the major aetiological agent of oropharyngeal candidosis associated with infection with the human immunodeficiency virus (HIV) $[1,2]$. The secreted aspartyl proteinases (Sap) of this opportunist fungus are considered to be important virulence factors that play a major role in the initiation and exacerbation of candida infections [3, 4]. Nine Sap iso-enzymes have been associated with $C$. albicans virulence [5-7], and these are differentially expressed during the yeast-tohyphal transition and phenotypic switching [8] of this dimorphic fungus. However, Sap2 has been shown to

Received 28 May 1998; revised version accepted 24 Nov 1998

Corresponding author: Prof. L. P. Samaranayake (e-mail: lakshman@hkucc.hku.hk).

${ }^{\ddagger}$ Present address: Division of Bacterial and Mycotic Diseases, Center for Disease Control and Prevention, Altanta, GA 30333, USA. be the predominant iso-enzyme secreted extracellularly by most $C$. albicans strains [5-7].

Saliva, the principal fluid that bathes oral sites colonised by $C$. albicans, contains several antimicrobial proteins including secreted immunoglobulins, lysozyme (muramidase), lactoferrin, histatins and the peroxidase system [9]. Among these proteins, lactoferrin and peroxidase are likely to be proteolytically degraded in the same manner as the secreted immunoglobulins, but lysozyme is resistant to this proteolytic activity because of its basic iso-electric point and high charge [10]. An earlier report describing the candidacidal activity of lysozyme [11] has been verified [12] and indicates that saliva is likely to modulate the Sap activity of $C$. albicans. In a previous study, with a single isolate of $C$. albicans, Germaine and Tellefson [13] reported that saliva was a potent inhibitor of the Sap activity. Subsequent in-vitro investigations have shown that, under appropriate conditions, $C$. albicans is capable of breaking down some salivary proteins but does not degrade lysozyme $[10,12,14]$. No other studies on the effect of saliva or its anti-candidal constituents, such as 
lysozyme, on Sap secretion by $C$. albicans have been reported.

Therefore, in-vitro investigations were undertaken to study the effect of lysozyme on Sap2 concentration and activity in oral isolates of $C$. albicans, employing spectrophotometry, enzyme-linked immunosorbent assay (ELISA), immunoblotting and ultrastructural features of lysozyme-exposed cells.

\section{Materials and methods}

\section{Organisms and culture media}

Five proteolytic C. albicans isolates (BM20617, BS742, BU1010, BU47204 and CA020-2) from the oral cavity were used. These were from patients with HIV infection with CD4 cell counts $<400$ cells $/ \mathrm{mm}^{3}$. The identity of the isolates was confirmed by sugar assimilation reactions with API $20 \mathrm{C}$ strips and by the germ-tube test [15]. They were cultured in YCB-BSA medium - yeast carbon base $23.4 \mathrm{~g}$, yeast extract $2.0 \mathrm{~g}$ (Difco) and bovine serum albumin (BSA; Sigma) $4.0 \mathrm{~g} / \mathrm{L}$, adjusted to $\mathrm{pH} 5.0$ and filter sterilised - to induce proteinase expression as described previously [6].

\section{Lysozyme preparation}

Hen egg-white lysozyme (enzyme activity $48000 / \mathrm{mg}$; Sigma) was used; $1 \mathrm{U}$ produces a $\Delta \mathrm{A}_{450}$ of $0.001 / \mathrm{pmin}$ at $\mathrm{pH} 6.24$ at $25^{\circ} \mathrm{C}$, with a suspension of Micrococcus lysodeikticus as the substrate. In the current study, this enzyme was prepared as a stock solution at $500 \mu \mathrm{g} / \mathrm{ml}$ and added to YCB-BSA medium to give final concentrations of $0,1,2.5,5,10,15$ and $20 \mu \mathrm{g} / \mathrm{ml}$. As normal oral concentrations of lysozyme range from 1 to $20 \mu \mathrm{g} / \mathrm{ml}$ [9], the concentrations tested in this study could be achieved easily in vivo.

Because of the likelihood that contaminants in hen eggwhite lysozyme (such as ammonium ions) could contribute to its antifungal effect and as egg-white is known to contain agents other than lysozyme, heatinactivated lysozyme (boiled in SDS $1 \%$ for $5 \mathrm{~min}$ ) was also evaluated to compare its effect on Sap activity and concentration.

\section{Growth of $C$. albicans in YCB-BSA medium with or without lysozyme}

Each of the five $C$. albicans isolates was pre-cultured in YCB-BSA medium for $24 \mathrm{~h}$ at $30^{\circ} \mathrm{C}$, harvested, washed twice with sterile saline, then transferred into fresh YCB-BSA medium with an initial inoculum of $1.0 \times 10^{6}$ cells $/ \mathrm{ml}$ (by haemocytometric count). Hen egg-white lysozyme was added to the cell suspensions to yield final concentrations of $0,1,2.5,5,10,15$ and $20 \mu \mathrm{g} / \mathrm{ml}$. The suspensions were incubated for $24 \mathrm{~h}$ with agitation at $150 \mathrm{rpm}$ at $37^{\circ} \mathrm{C}$, to evalute the inhibitory effect of lysozyme on yeast cell growth.
Samples were then plated on Sabouraud's dextrose agar and yeast cell viability was determined by assessment of the cfu produced after incubation for $24 \mathrm{~h}$ at $37^{\circ} \mathrm{C}$. A lysozyme-free control consisting of $C$. albicans grown in YCB-BSA medium was included in each experiment.

\section{Assessment of extracellular Sap concentration and activity}

The two methods employed to determine the effect of lysozyme on Sap in vitro were spectrophotometry to measure enzyme activity [16] and ELISA to determne Sap concentration, where the enzyme acted as the antigen [17]. To evaluate whether lysozyme had any adverse effect on the constituents of the spectrophotometry assay or the ELISA, a 'blank' control, containing YCB-BSA medium and hen egg-white lysozyme $(10 \mu \mathrm{g} / \mathrm{ml})$ alone, was used in both assays.

\section{Spectrophotometric assessment of Sap activity}

Each assay consisted of $0.1 \mathrm{ml}$ of culture supernate and $0.4 \mathrm{ml}$ of $0.1 \mathrm{M}$ sodium citrate buffer ( $\mathrm{pH} \mathrm{3.2)}$ ) containing BSA $1 \% \mathrm{w} / \mathrm{v}$. The control consisted of identical ingredients plus pepstatin A (Sigma) $50.0 \mu \mathrm{g} / \mathrm{ml}$, which inhibited the proteinase activity. After incubation at $37^{\circ} \mathrm{C}$ for $15 \mathrm{~min}$, the reaction was stopped by addition of $5 \mathrm{ml}$ of trichloroacetic acid (TCA) $5 \%$ on ice. Samples were then centrifuged at $1500 \mathrm{~g}$ for $10 \mathrm{~min}$, and the $\mathrm{A}_{280}$ of the supernate was read against a blank containing distilled water. Enzyme activity was expressed as the amount, in micromoles, of tyrosine equivalents released $/ \mathrm{min} / \mathrm{ml}$ of culture supernate [18].

\section{Detection of Sap by ELISA}

Sap concentration was also quantified by an ELISA with antibody raised against purified Sap2 from $C$. albicans strain ATCC 10261 in a New Zealand White rabbit [17]; $100 \mu \mathrm{l}$ of the culture supernate were mixed with $0.5 \mathrm{ml}$ of TCA $50 \% \mathrm{w} / \mathrm{v}$, incubated for $30 \mathrm{~min}$ on ice and centrifuged at $1500 \mathrm{~g}$ for $10 \mathrm{~min}$. Pellets were washed twice with ethanol $95 \%$, dissolved in SDS $1 \%$, boiled for $3 \mathrm{~min}$, diluted in $0.2 \mathrm{M}$ sodium carbonate buffer, ( $\mathrm{pH} 9.5)$ and applied $(70 \mu \mathrm{l})$ to the microtest plates (Microelisa, Dynatech, Chantilly, VA, USA). The plates were incubated overnight at $4^{\circ} \mathrm{C}$, rinsed three times with $0.1 \mathrm{M}$ phosphate-bufffered saline (PBS, $\mathrm{pH} 7.4$ ) containing Tween $200.05 \% \mathrm{v} / \mathrm{v}$ (TPBS) and blocked with $w / v$ BSA $1 \%$-PBS for $1 \mathrm{~h}$ at $37^{\circ} \mathrm{C}$. The rabbit anti-Sap antibody $(100 \mu 1)$ was added at a 1 in 500 dilution in TPBS $0.05 \%$ and incubated for $2 \mathrm{~h}$ at $37^{\circ} \mathrm{C}$. After washing three times with TPBS $0.05 \%$, $100 \mu \mathrm{l}$ of phosphatase-conjugated goat anti-rabbit IgG ( 1 in 1000 dilution; Sigma) were added and incubated for $2 \mathrm{~h}$ at $37^{\circ} \mathrm{C}$. The reaction used the phosphatase substrate, nitrophenyl phosphate, for colorimetric detection and was stopped after $20 \mathrm{~min}$ by the addition of $20 \mu \mathrm{l}$ of $3 \mathrm{M} \mathrm{NaOH}$. The plates were read with an automated microtitration plate reader (BioRad, Her- 
cules, CA, USA) at $405 \mathrm{~nm}$, blanked against air. The amounts of proteinase were calculated from a standard curve $(1-110 \mathrm{ng})$ constructed with purified Sap as coating antigen under the conditions described above. Reaction controls included tests conducted either without antibody, or without coating antigen.

\section{Western blotting to detect extracellular Sap}

Supernates from YCB-BSA cultures exposed to lysozyme $10 \mu \mathrm{g} / \mathrm{ml}$ were harvested after incubation for $24 \mathrm{~h}$. SDS-PAGE of supernates was performed with a $10 \% \mathrm{w} / \mathrm{v}$ gel in a vertical slab gel apparatus (Hoefer, San Francisco, CA, USA) for $1.5 \mathrm{~h}$ at $150 \mathrm{~V}$ and $20 \mathrm{~mA}$ at $4^{\circ} \mathrm{C}$. The sample protein load in each lane was $300 \mathrm{ng}$ as quantified by a Coomassie Blue reaction. Coloured protein mol.-wt markers (Rainbow, Americhrom Global Technologies, Burtonsville, MD, USA), which included myosin (220000), phosphorylase b (97400), BSA (66000), ovalbumin (46000), carbonic anhydrase (30000) and trypsin inhibitor (21 500), were used for gels prepared for Western blotting. Electrophoretic transfer of proteins from polyacrylamide gel to nitrocellulose membranes was achieved with a semi-dry electrophoretic transfer cell (BioRad) for $1 \mathrm{~h}$ at $15 \mathrm{~V}$ and $180 \mathrm{~mA}$. After a complete transfer, as verified by silver staining, the membrane was incubated with BSA $3 \%$ in $0.1 \mathrm{M}$ Tris-buffered saline (TBS), $\mathrm{pH} 7.6$ for $1 \mathrm{~h}$ at $37^{\circ} \mathrm{C}$ and then with rabbit anti-Sap antibody (diluted 1 in 500) in BSA $1 \%$-TBS for $2 \mathrm{~h}$ at $37^{\circ} \mathrm{C}$ with gentle agitation. Afterwards, the membrane was rinsed twice for $10 \mathrm{~min}$ in TBS containing Tween $20 \quad 0.05 \%$ (TTBS), then once briefly with distilled water, and incubated with secondary antibody (goat anti-rabbit IgG-peroxidase conjugate) diluted 1 in 1000 in BSE $1 \%$-TBS. After rinsing in TTBS twice for $10 \mathrm{~min}$ and then once with distilled water, the membrane was exposed to the chromogenic substrate (diaminobenzidine $10 \mathrm{mg}$ in $15 \mathrm{ml}$ TBS, $\mathrm{pH} 7.6$ ) plus $15 \mu \mathrm{l}$ of $\mathrm{H}_{2} \mathrm{O}_{2}$ (Sigma) 35\%. Developed Western blots were scanned and analysed by ImageMaster Software (Pharmacia Biotech AB, Uppsala, Sweden). The relative density (RD) values were quantified by calculating the average density and integrating over the band width. The amount of proteinase was calculated from a standard curve, determined by a Western blot developed with concentrations of purified Sap from 1 to $150 \mathrm{ng}$.

\section{Analysis of intracellular Sap concentration and activity}

The effect of lysozyme on intracellular Sap concentration and activity was studied. For this purpose, each of the five $C$. albicans isolates was grown in YCB-BSA medium for $48 \mathrm{~h}$ at $37^{\circ} \mathrm{C}$ with or without hen egg-white lysozyme $(10 \mu \mathrm{g} / \mathrm{ml})$. Cells were harvested and washed twice by centrifugation in PBS for $10 \mathrm{~min}$ at $5000 \mathrm{rpm}$ to form a cell pellet. Cells in the pellet were disrupted by freezing-thawing as recommended by Sprott et al. [19]. A washed cell pellet was frozen in liquid nitrogen and then ruptured thoroughly by grinding the frozen cells with a pestle in a pre-cooled mortar. The lysed cells were resuspended to the original volume with PBS and centrifuged at $15000 \mathrm{~g}$ for $10 \mathrm{~min}$. The soluble cytoplasmic proteins in supernates and the insoluble cell pellets were then tested separately for proteolytic enzyme activity (by spectrophotometry) and antigen concentration (by ELISA). Western blotting was performed to confirm the presence of Sap in both preparations.

\section{$p H$ assay of the yeast cell culture}

The effect of lysozyme (a highly charged enzyme), on the $\mathrm{pH}$ fluctuations of the test medium for the duration of the experiment $\left(60 \mathrm{~h}, 37^{\circ} \mathrm{C}\right)$ was investigated by monitoring the $\mathrm{pH}$ of the following media: (a) YCBBSA medium alone, (b) YCB-BSA plus lysozyme $10 \mu \mathrm{g} / \mathrm{ml}$, (c) C. albicans BM20617 $1 \times 10^{6}$ cells $/ \mathrm{ml}$ in YCB-BSA medium and (d) the latter suspension with lysozyme $10 \mu \mathrm{g} / \mathrm{ml}$. A pH meter (Corning Instruments, NY, NY, USA) was calibrated with standard buffers before use.

\section{Direct effect of lysozyme on purified Sap}

To test the stability of purified Sap in the presence of lysozyme under the growth conditions used, purified Sap from C. albicans strain ATCC 10261 (Sap concentration $=364.5 \mathrm{mmol} / \mathrm{ml} / \mathrm{min}$ in YCB-BSA medium was incubated with or without lysozyme $10 \mu \mathrm{g} / \mathrm{ml}$ for $24 \mathrm{~h}$ at $37^{\circ} \mathrm{C}$. Sap enzymic activity and antigen concentration were measured by spectrophotometry and ELISA, respectively.

\section{Scanning electron microscopy}

To evaluate the effect of lysozyme on the ultrastructure of C. albicans, cells were cultured in YCB-BSA medium for $24 \mathrm{~h}$ with or without lysozyme $(\mathrm{O}, 5,10$ and $15 \mu \mathrm{g} / \mathrm{ml}$, harvested by centrifugation at $1500 \mathrm{~g}$ for $10 \mathrm{~min}$, fixed in glutaraldehyde $2.5 \%$ in PBS at $4^{\circ} \mathrm{C}$ for $16 \mathrm{~h}$ and stained with osmium tetroxide. The specimens were then mounted on copper grids, coated with gold to a thickness of $15-20 \mathrm{~nm}$ and examined with a Leica S-440 scanning electron microscope (Leica Instruments, Berlin, Germany).

\section{Statistical analysis}

Two-way analysis of variance (ANOVA) was used to evaluate the effect of lysozyme on the viability of $C$. albicans and on extracellular Sap activity and concentration. Student's $t$ test was employed to analyse the effect of lysozyme on the intracellular Sap concentration in C. albicans, compare the effect of lysozyme and its inactivated form on Sap production by $C$. albicans and compare the ability of strains BS742 and BU1010 to grow in YCB-BSA medium without lysozyme. Finally, linear regression analysis was used to evaluate the relationship between spectrophotometry, ELISA and Western blot results. 


\section{Results}

\section{Effect of lysozyme on the growth of C. albicans}

The effect of different concentrations of hen egg-white lysozyme on yeast cell viability is shown in Table 1 . After incubation for $24 \mathrm{~h}$, viability was reduced when the lysozyme concentration was $>10 \mu \mathrm{g} / \mathrm{ml}(\mathrm{p}<0.05)$; below this concentration, no significant effect on yeast cell viability was observed ( $p>0.05$, Table 1$)$. Innate differences in susceptibility to inhibition by lysozyme were evident among genetically distinct strains of $C$. albicans. For example, treatment of strain BU1010 with lysozyme $20 \mu \mathrm{g} / \mathrm{ml}$ resulted in a 9.4-fold decrease in the recovery of $\mathrm{cfu} / \mathrm{ml}$, whereas identical treatment resulted in a significant but only 2.7 -fold decrease in viability of strain CA020-2 (Table 1). Strains also showed some variation in their capacity to grow in YCB-BSA medium even in the absence of lysozyme, i.e., although the initial inoculum was identical, after $24 \mathrm{~h}$, strain BS742 has $29 \%$ more recoverable cfu $/ \mathrm{ml}$ than strain BU1010, $p<0.05$ (Table 1). As the first five

Table 1. Effect of hen egg-white lysozyme on the cell viability of five $C$. albicans isolates

\begin{tabular}{|c|c|c|}
\hline Isolate no. & $\begin{array}{c}\text { Lysozyme } \\
\text { concentration } \\
(\mu \mathrm{g} / \mathrm{ml})\end{array}$ & $\begin{array}{l}\text { Cell viability } \\
\text { Mean (SD) } \\
\text { cfu }\left(\times 10^{6}\right) / \mathrm{ml}\end{array}$ \\
\hline BM20617 & $\begin{array}{l}0 \\
1 \\
2.5 \\
5 \\
10 \\
15 \\
20\end{array}$ & $\begin{array}{r}18.07(0.33) \\
17.98(0.26) \\
17.96(0.42) \\
18.40(0.43) \\
18.07(0.11) \\
11.82(0.73)^{\dagger} \\
5.07(0.62)^{\dagger}\end{array}$ \\
\hline BS742 & $\begin{array}{l}0 \\
1 \\
2.5 \\
5 \\
10 \\
15 \\
20\end{array}$ & $\begin{array}{r}18.11(0.98) \\
18.74(1.03) \\
18.07(0.57) \\
18.11(1.06) \\
18.07(1.04) \\
10.83(0.94)^{\dagger} \\
6.25(0.83)^{\dagger}\end{array}$ \\
\hline BU1010 & $\begin{array}{l}0 \\
1 \\
2.5 \\
5 \\
10 \\
15 \\
20\end{array}$ & $\begin{array}{r}12.79(0.20) \\
13.37(0.18) \\
12.91(0.57) \\
12.85(0.41) \\
11.90(0.82) \\
6.28(0.54)^{\dagger} \\
1.36(0.33)^{\dagger}\end{array}$ \\
\hline BU47204 & $\begin{array}{l}0 \\
1 \\
2.5 \\
5 \\
10 \\
15 \\
20\end{array}$ & $\begin{array}{r}16.86(0.45) \\
15.91(0.93) \\
16.74(0.50) \\
16.91(0.68) \\
16.29(0.97) \\
8.54(1.00)^{\dagger} \\
5.48(1.38)^{\dagger}\end{array}$ \\
\hline $\mathrm{CA020-2}$ & $\begin{array}{l}0 \\
1 \\
2.5 \\
5 \\
10 \\
15 \\
20\end{array}$ & $\begin{array}{c}17.58(1.17) \\
17.91(0.78) \\
17.37(1.12) \\
17.66(1.18) \\
17.45(1.15) \\
10.33(0.98)^{\dagger} \\
6.53(0.88)^{\dagger}\end{array}$ \\
\hline
\end{tabular}

Mean (SD) from three separate experiments.

${ }^{\dagger}$ Significantly different from control samples containing no lysozyme $(\mathrm{p}<0.05)$. dilutions of lysozyme had no detectable effect on yeast cell growth, they were used to evaluate the effect of lysozyme on extracellular and intracellular Sap activity and concentration.

\section{Effect of lysozyme on the ultrastructure of $C$. albicans}

Although no effect on yeast cell viability was observed after exposure to lysozyme concentrations below $10 \mu \mathrm{g} / \mathrm{ml}$ for a $24-\mathrm{h}$ period, adverse morphological alterations of the cell surface were evident by scanning electron microscopy. Typical photomicrographs of strain BM20617 after exposure to hen egg-white lysozyme at 5 and at $10 \mu \mathrm{g} / \mathrm{ml}$ are shown in Fig. $1 \mathrm{~b}$ and $\mathrm{c}$, respectively. Compared with untreated control cells (Fig. 1a), the yeast cells exposed to lysozyme were ballooned, with or without invaginations, and some cells appeared collapsed and deflated (Figs. 1b and $\mathrm{c}$ ). The invaginations were particularly frequent amongst bud scars. When the isolate was exposed to a higher concentration of lysozyme $(15 \mu \mathrm{g} / \mathrm{ml})$, further deterioration of cellular structure was evident (Fig. 1d). Similar morphological changes induced by lysozyme were evident amongst other strains tested.

\section{Effect of lysozyme on yeast cell growth, Sap activity and culture $\mathrm{pH}$}

Cell growth and Sap activity of five C. albicans isolates incubated with lysozyme $10 \mu \mathrm{g} / \mathrm{ml}$ for $60 \mathrm{~h}$ were compared. The results of a representative experiment with isolate BM20617 are shown in Fig. 2. Similar results were obtained with the other strains tested. The presence of lysozyme $10 \mu \mathrm{g} / \mathrm{ml}$ had no detectable effect on the growth of isolate BM20617 during incubation for $60 \mathrm{~h}$ when compared with growth in lysozyme-free medium. In both the control and the test samples, the log phase of growth lasted for up to $24 \mathrm{~h}$ and then the cell numbers declined. Similar effects of lysozyme on growth and Sap activity were found in the other strains tested (data not shown).

In contrast to yeast cell growth, Sap activity was consistently lower in the treated samples than in the lysozyme-free control samples $(p<0.05)$. However, in both the treated and control samples, Sap activity peaked at $45 \mathrm{~h}$ and declined thereafter (Fig. 2). This trend was observed for all the test strains. When the data on Sap activity and yeast cell growth were compared, it was found that the enzyme activity peaked after growth had become stationary (Fig. 2). Lysozyme had no direct effect on culture $\mathrm{pH}$ (Fig. 3) indicating that lysozyme did not exert its Sap inhibitory effect via a direct alteration of culture $\mathrm{pH}$ (which could affect the $\mathrm{pH}$ optimum for Sap activity). However, treatment of $C$. albicans with lysozyme $10 \mu \mathrm{g} / \mathrm{ml} \mathrm{did}$ inhibit the characteristic drop in extracellular $\mathrm{pH}$ observed in the absence of lysozyme (Fig. 3). 


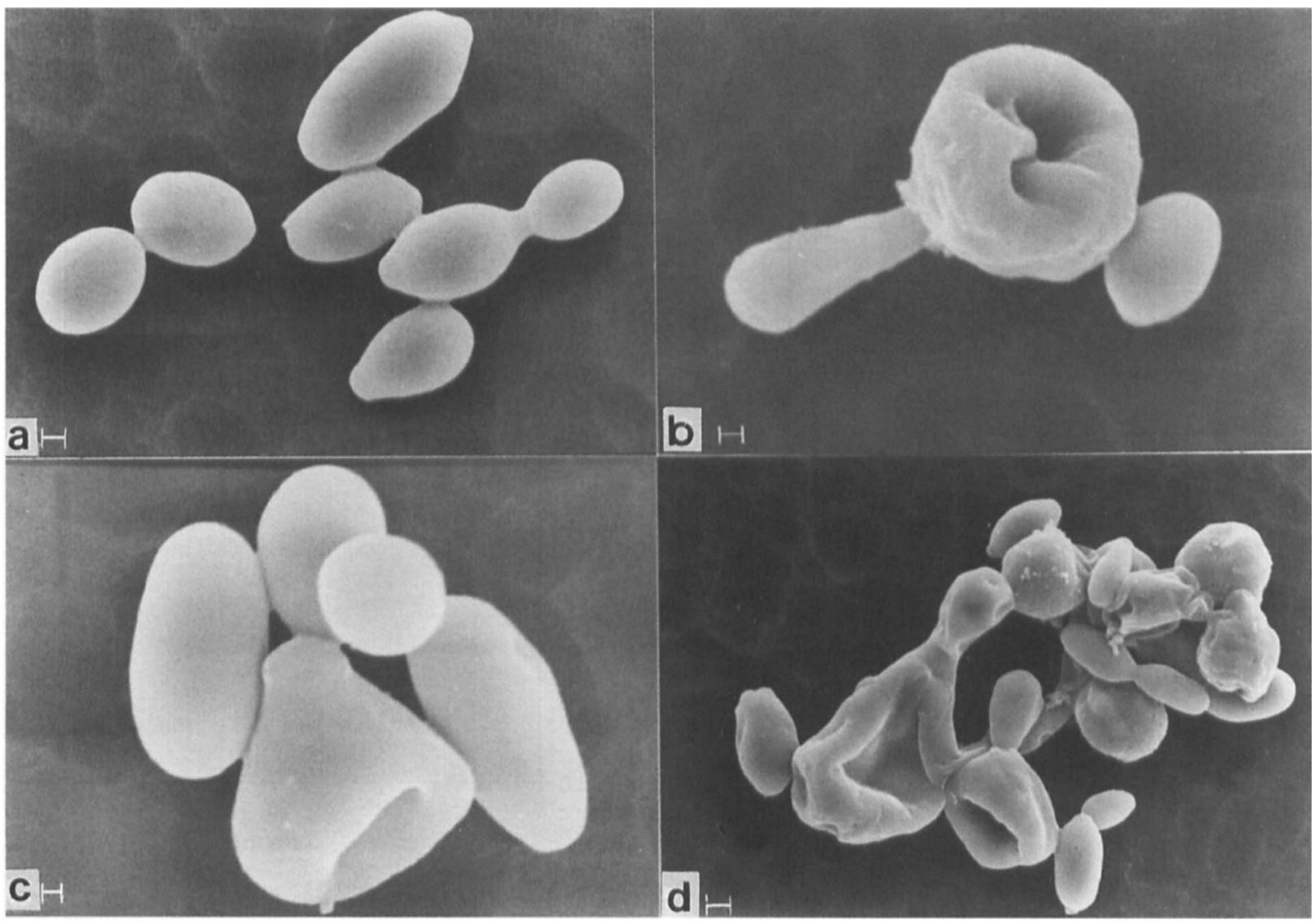

Fig. 1. Effect of different concentrations of lysozyme on C. albicans BM20617 ultrastructure as revealed by scanning electron microscopy: (a) no lysozyme, (b) $5 \mu \mathrm{g} / \mathrm{ml}$, (c) $10 \mu \mathrm{g} / \mathrm{ml}$, (d) $15 \mu \mathrm{g} / \mathrm{ml}$ (bar $=0.7 \mu \mathrm{m}$ ).

\section{Dose-dependent effect of lysozyme on extracellular Sap activity and concentration}

Sap activity of $C$. albicans isolates was evaluated by spectrophotometry and Sap concentration by ELISA, after incubation for $24 \mathrm{~h}$ with different amounts of lysozyme. Findings from these two evaluations, conducted on three separate occasions, are presented in Table 2. Lysozyme exerted a dose-related attenuating effect on Sap activity as well as on Sap concentration, at $1-10 \mu \mathrm{g} / \mathrm{ml}$. Regression analysis demonstrated a highly significant positive correlation between the reduction in enzyme activity as measured by spectrophotometry $(\mathrm{mmol} / \mathrm{ml} / \mathrm{min})$ and the Sap antigen concentration as measured by ELISA (ng/ml) $(\mathrm{r}=0.8224, \mathrm{p}<0.0001)$.

As observed in experiments examining the effects of lysozyme on cell viability, innate differences in Sap inhibition in response to lysozyme treatment were observed among genetically distinct $C$. albicans strains (Table 2). Whereas Sap activity was reduced at least two-fold by lysozyme $10 \mu \mathrm{g} / \mathrm{ml}$ for all strains, reduction of Sap concentration was as much as 4-9-fold depending upon the strain observed (Table 2). However, within the same strain, lysozyme significantly reduced both Sap activity and concentration in a dosedependent manner (Table 2). The effects of lysozyme were apparent although testing occurred at a $\mathrm{pH}$ that was less than optimal for this enzyme (optimum $\mathrm{pH}$ range: $6.0-9.0$ ).

\section{Western blots of culture supernates}

Western blotting was performed to confirm that the antigen detected by ELISA was Sap2 (Fig. 4). In all cases, the Sap antiserum reacted strongly with a 43$\mathrm{kDa}$ protein in the culture medium that had a $\mathrm{M}_{\mathrm{r}}$ identical with that of purified Sap2 (Fig. 4) [4]. However, Western blots of Sap from strains BS742, BU1010, BU47204 and CA020-2 also showed lower mol. wt bands of c. $41 \mathrm{kDa}$, indicating that some strains may produce more than one iso-enzyme of Sap. Furthermore, it appears that genetically different strains of $C$. albicans not only produce varying amounts of Sap iso-enzymes, but also the total Sap produced varies among strains grown under identical conditions. When the data from a quantitative analysis of the Western blot were compared to the ELISA data of the same sample, a very high degree of concordance was found between the two assays $(r=0.9986, p<0.0001)$.

\section{Effect of lysozyme on intracellular Sap concentration and activity}

The effect of lysozyme on intracellular Sap concentration and activity or its precursor forms was studied in three separate experiments. No enzyme activity was 


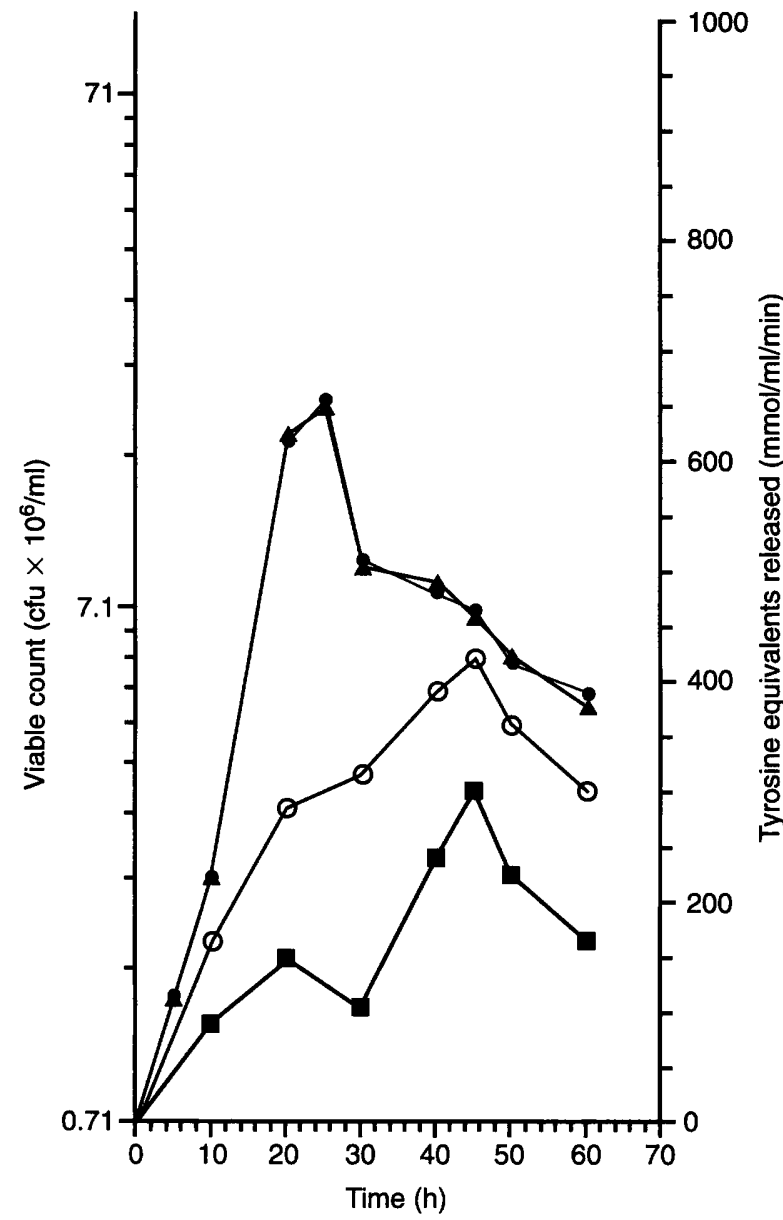

Fig. 2. Effect of lysozyme treatment $(10 \mu \mathrm{g} / \mathrm{ml})$ on growth $(\bullet, \boldsymbol{\Delta})$ and extracellular Sap activity $(\mathrm{O}, \boldsymbol{\square})$ of C. albicans BM20617. Growth was determined by the yield of cfu from samples taken from the test $(\boldsymbol{\Delta}, \boldsymbol{\square})$ and control $(\bullet, O)$ yeast suspensions at intervals and grown on Sabouraud's dextrose agar plates. Sap activity was measured by BSA hydrolysis by spectrophotometry.

detected in either the soluble cytoplasmic or the insoluble pellet fractions of 48 -h yeast cultures. However, intracellular Sap concentration, found in the soluble cytoplasmic fractions of five isolates exposed to lysozyme $10 \mu \mathrm{g} / \mathrm{ml}$ for $48 \mathrm{~h}$ at $37^{\circ} \mathrm{C}$ determined by ELISA, was two- to almost four-fold higher than in fractions from control yeast cells not exposed to lysozyme (Table 3). Probing this fraction in a Western blot with anti-Sap antibody revealed several positively reacting bands from 17 to $65 \mathrm{kDa}$ (Fig. 5, lanes 4 and 5). Taken together with data shown in Table 2 where extracellular Sap concentration was reduced following lysozyme treatment, lysozyme appears to either promote production of intracellular Sap or its precursor form, or both, or to depress the release of the intracellular enzyme into the extracellular milieu. The reactive bands at 45 and $65 \mathrm{kDa}$ may indicate that Saps are of greater $\mathrm{M}_{\mathrm{r}}$ intracellularly before being cleaved and secreted into the extracellular environment.

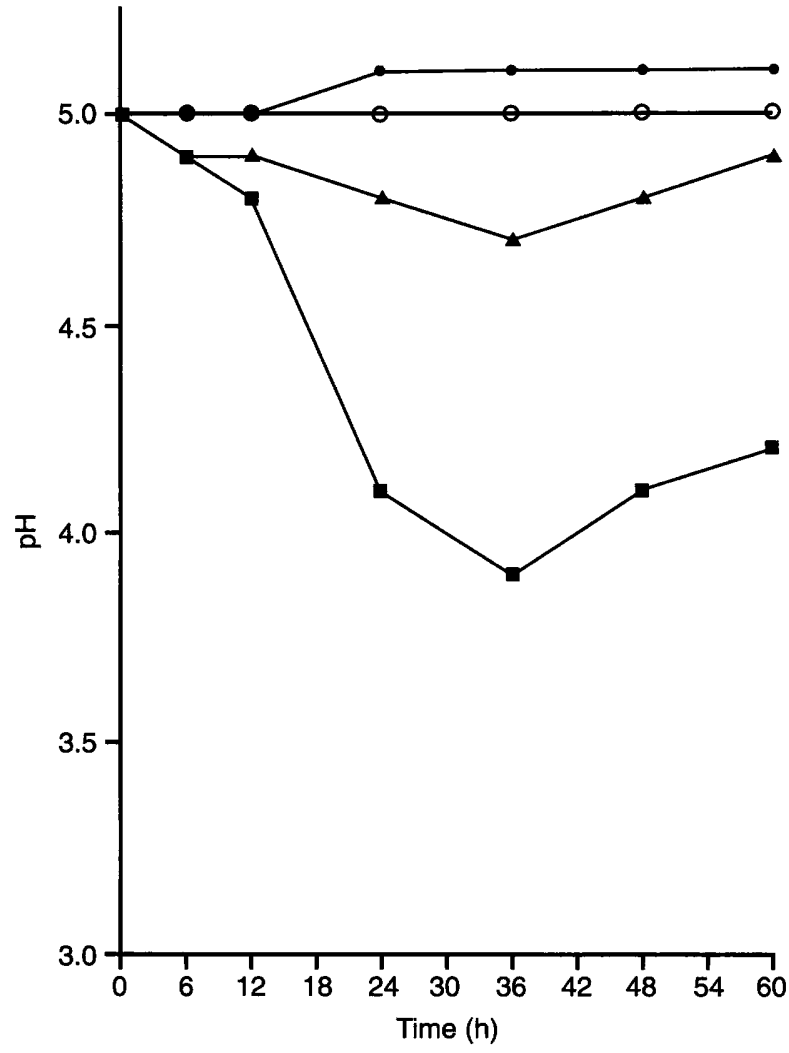

Fig. 3. Effect of lysozyme treatment on the $\mathrm{pH}$ of YCBBSA culture with $C$. albicans BM20617: O, YCB-BSA control; •, YCB-BSA + lysozyme $10 \mu \mathrm{g} / \mathrm{ml}$; $\mathbf{a}$, YCB$\mathrm{BSA}+$ C. albicans BM20617; $\boldsymbol{\Delta}$, YCB-BSA + lysozyme $10 \mu \mathrm{g} / \mathrm{ml}+$ C. albicans BM20617.

Table 2. Dose-dependent effect of lysozyme on $C$. albicans extracellular SAP activity and concentration

\begin{tabular}{lcccc}
\hline $\begin{array}{l}\text { Isolate } \\
\text { no. }\end{array}$ & $\begin{array}{c}\text { Lysozyme } \\
\text { concentration } \\
(\mu \mathrm{g} / \mathrm{ml})\end{array}$ & $\begin{array}{c}\text { Mean (SD) } \\
\text { SAP activity* } \\
(\mathrm{mmol} / \mathrm{ml} / \mathrm{min})\end{array}$ & $\begin{array}{c}\text { Mean (SD) SAP } \\
\text { concentration* } \\
(\mathrm{ng} / \mathrm{ml})\end{array}$ \\
\hline BM20617 & 0 & $293.0(14.3)$ & $215.3(17.7)$ \\
& 1 & $214.0(16.8)$ & $115.5(12.3)$ \\
& 2.5 & $158.5(14.3)$ & $95.1(11.6)$ \\
BS742 & 5 & $124.0(26.5)$ & $61.7(13.1)$ \\
& 10 & $119.3(9.5)$ & $35.6(4.3)$ \\
& 0 & $236.3(5.9)$ & $200.2(24.8)$ \\
& 1 & $171.0(12.7)$ & $140.3(14.5)$ \\
BU1010 & 2.5 & $144.0(11.7)$ & $154.6(15.9)$ \\
& 5 & $107.0(6.9)$ & $94.3(11.2)$ \\
& 10 & 95.5 & $(8.0)$ & $50.6(5.2)$ \\
& 0 & $135.0(7.5)$ & $174.7(9.2)$ \\
BU47204 & 1 & $104.5(11.2)$ & $91.7(4.1)$ \\
& 2.5 & $69.5(13.1)$ & $54.1(10.8)$ \\
& 5 & $73.0(12.7)$ & $39.5(5.1)$ \\
& 10 & $72.5(18.8)$ & $15.5(3.8)$ \\
& 0 & $306.0(18.4)$ & $251.2(18.4)$ \\
& 1 & $252.5(9.0)$ & $133.7(21.1)$ \\
CA020-2 & 2.5 & $194.0(9.0)$ & $116.9(24.3)$ \\
& 5 & $175.0(12.2)$ & $61.2(9.9)$ \\
& 10 & $188.5(20.5)$ & $55.5(6.6)$ \\
& 0 & $325.0(32.0)$ & $292.6(17.7)$ \\
& 1 & $243.5(29.2)$ & $165.0(20.5)$ \\
& 2.5 & $202.5(21.0)$ & $166.3(8.2)$ \\
& 5 & $194.5(9.0)$ & $109.8(7.4)$ \\
& 10 & $175.5(9.5)$ & $49.1(9.8)$ \\
\hline
\end{tabular}

*Two-way ANOVA, $\mathrm{p}$ value $<0.0001$ (between the lysozyme-free control and all test samples). 


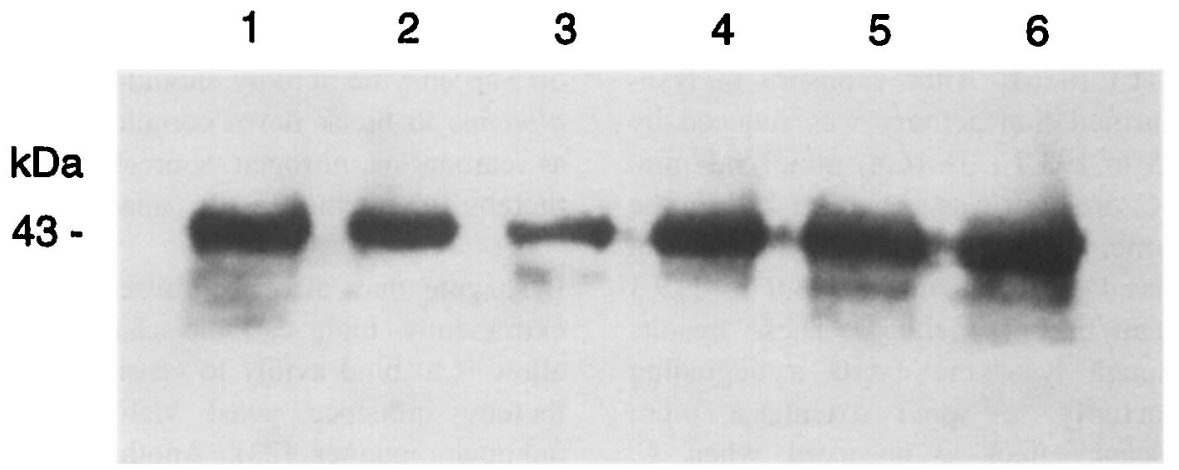

Fig. 4. Western blot of 24-h culture supernates from five $C$. albicans isolates grown in YCB-BSA medium exposed to lysozyme $10 \mu \mathrm{g} / \mathrm{ml}$. Lane 1, C. albicans BM20617; 2, C. albicans BS742; 3, C. albicans BU1010; 4, C. albicans BU47204; 5, C. albicans CA020-2; 6, purified Sap of C. albicans strain ATCC 10261 (43 kDa).

Table 3. Effect of lysozyme on intracellular SAP concentration and activity of $C$. albicans

\begin{tabular}{lccc}
\hline $\begin{array}{l}\text { Isolate } \\
\text { no. }\end{array}$ & $\begin{array}{c}\text { Lysozyme } \\
\text { concentration } \\
(\mu \mathrm{g} / \mathrm{ml})\end{array}$ & $\begin{array}{c}\text { Mean (SD) } \\
\text { SAP concentration } \\
(\mathrm{ng} / \mathrm{ml})\end{array}$ & $\begin{array}{c}\text { SAP activity } \\
(\mathrm{mmol} / \mathrm{ml} / \mathrm{min})\end{array}$ \\
\hline BM20617 & 0 & $160.0(19.7)$ & 0 \\
& 10 & $617.5(22.6)^{\dagger}$ & 0 \\
BS742 & 0 & $207.4(18.6)$ & 0 \\
& 10 & $536.9(38.6)^{\dagger}$ & 0 \\
BU1010 & 0 & $158.6(32.9)$ & 0 \\
& 10 & $369.7(47.6)^{\dagger}$ & 0 \\
BU47204 & 0 & $228.5(18.4)$ & 0 \\
& 10 & $589.1(20.1)^{\dagger}$ & 0 \\
CA020-2 & 0 & $262.7(24.2)$ & 0 \\
& 10 & $587.6(50.6)^{\dagger}$ & 0 \\
\hline
\end{tabular}

${ }^{*}$ Mean and SD for three experiments.

${ }^{\dagger}$ Significantly different from controls (no lysozyme) by Student's $t$ test $(\mathrm{p}<0.0001)$.

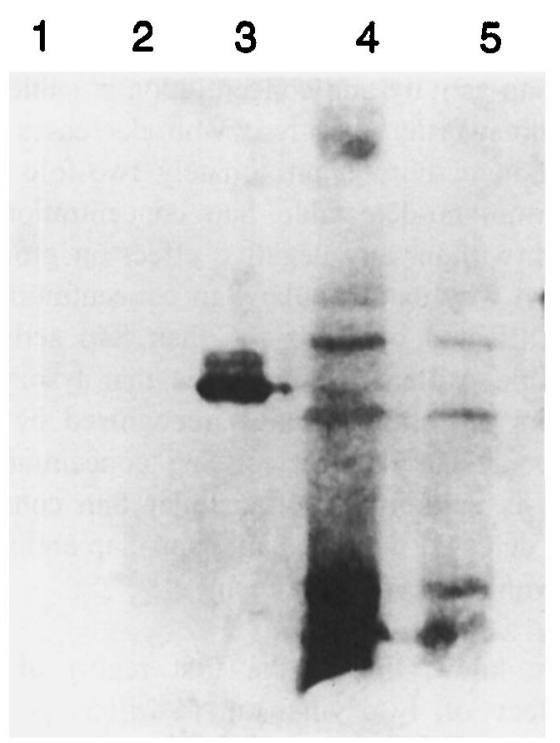

$\mathrm{kDa}$

Fig. 5. Western blot of the intracellular Sap of $C$. albicans BM20617. Lane 1, cell pellets from $C$. albicans exposed to lysozyme $(10 \mu \mathrm{g} / \mathrm{ml}) ; 2$, cell pellets from $C$. albicans cultures without lysozyme; 3 , purified Sap from C. albicans strain ATCC $10261(43 \mathrm{kDa}) 4$, soluble cytoplasmic proteins from $C$. albicans cells exposed to lysozyme $(10 \mu \mathrm{g} / \mathrm{ml}) ; \mathbf{5}$, soluble cytoplasmic proteins from $C$. albicans cells grown without lysozyme.

\section{Effect of inactivated lysozyme on Sap from $C$.} albicans isolates

Heat-inactivated lysozyme was tested for its effect on Sap activity and concentration, to identify possible artifacts caused by contaminants in the lysozyme preparation. No significant effect on extracellular Sap activity or concentration was observed when cells were grown in the presence of inactivated lysozyme (Table $4 ; \mathrm{p}<0.05)$. Also, growth was not affected significantly by inactivated lysozyme $10 \mu \mathrm{g} / \mathrm{ml}$. Therefore, the effects caused by active lysozyme on Sap activity and concentration were directly due to the enzyme activity.

\section{Direct effect of lysozyme on Sap activity}

Purified Sap enzyme activity was stable for $24 \mathrm{~h}$ at $37^{\circ} \mathrm{C}$ under the experimental conditions used. To determine if lysozyme could have a direct effect on Sap in the absence of $C$. albicans cells, lysozyme

Table 4. Effect of lysozyme and inactivated lysozyme on extracellular SAP concentration and activity C. albicans

\begin{tabular}{lccr}
\hline & $\begin{array}{c}\text { Lysozyme } \\
\text { concentration } \\
\text { Isolate }\end{array}$ & $\begin{array}{c}\text { Mean (SD) } \\
\text { SAP activity } \\
\text { no. }\end{array}$ & $\begin{array}{c}\text { Mean (SD) } \\
\text { SAP } \\
\text { concentration } \\
(\mathrm{mg} / \mathrm{ml})\end{array}$ \\
\hline BM20617 & 0 & $293.0(15.6)$ & $215.3(18.2)$ \\
& 10 & $119.0(9.9)$ & $35.6(4.3)$ \\
& 10 (inactivated) & $298.1(14.2)$ & $218.0(15.7)$ \\
BS742 & 0 & $236.7(5.7)$ & $200.2(24.8)$ \\
& 10 & $95.5(7.8)$ & $50.6(5.2)$ \\
& 10 (inactivated) & $234.2(18.2)$ & $203.0(17.8)$ \\
BU1010 & 0 & $135.0(18.4)$ & $174.7(8.6)$ \\
& 10 & $72.5(19.1)$ & $15.5(3.8)$ \\
& 10 (inactivated) & $137.4(12.6)$ & $172.6(15.3)$ \\
BU47204 & 0 & $306.0(17.7)$ & $251.2(15.8)$ \\
& 10 & $188.5(2.5)$ & $55.5(6.6)$ \\
& 10 (inactivated) & $304.0(21.4)$ & $248.0(18.3)$ \\
CA020-2 & 0 & $325.0(32.5)$ & $292.6(17.7)$ \\
& 10 & $175.5(10.6)$ & $49.1(8.7)$ \\
& 10 (inactivated) & $328.0(26.1)$ & $297.0(18.6)$ \\
\hline
\end{tabular}

Significant differences between the inactivated lysozyme and the lysozyme-containing test samples $(t$ test, $\mathrm{p}<0.001)$; no significant difference between the inactivated lysozyme and lysozyme-free samples $(p>0.05)$. 
$10 \mu \mathrm{g} / \mathrm{ml}$ was co-incubated with purified Sap from $C$. albicans strain ATCC10261. After exposure to lysozyme for $24 \mathrm{~h}$, purified Sap activity was reduced by $19.4 \%$, from 364.5 to 293.7 (SD 16.8 ) $\mathrm{mmol} / \mathrm{ml} / \mathrm{min}$. In contrast, when $C$. albicans was grown for $24 \mathrm{~h}$ in the presence of lysozyme, a much greater reduction in Sap activity was observed - 59.3\%, from 293.0 to 119.3 (SD 9.5$) \mathrm{mmol} / \mathrm{ml} / \mathrm{min}(\mathrm{p}<0.05)$. These results indicate that although lysozyme exerts a degrading effect on Sap activity to some extent, a more profoundly significant effect is observed when $C$. albicans are grown in the presence of lysozyme.

\section{Discussion}

Lysozyme, also known as muramidase, is present in saliva and is derived from at least three different sources: the salivary glands, phagocytic cells and the gingival crevicular fluid [9]. Although there has been controversy in early studies on the effect of lysozyme on C. albicans [20,21], several recent investigations have shown that the yeast is either inhibited or rendered non-viable in vitro by its activity, which is modulated to a great extent by the characteristics of the culture medium [11]. The current study showed that lysozyme reduced cell viability, but only at a concentration $>10 \mu \mathrm{g} / \mathrm{ml}$. This result differs from previous reports in which yeast cell growth was inhibited at much lower concentrations of lysozyme $(0.5 \mu \mathrm{g} / \mathrm{ml})$ [11]. One reason for this disparity could be the source of $C$. albicans strains, which were isolated from patients with HIV infection, and another could be that the present study used YCB-BSA medium to induce Sap production. Interestingly, preliminary data from this laboratory indicate that isolates from HIV-infected individuals are more resistant to the candidacidal effect of lysozyme than those from HIV-free individuals. Indeed, even within this study, different isolates were affected to different degrees by exposure to lysozyme, indicating that there are innately different responses to the action of lysozyme among genetically distinct isolates of $C$. albicans. Nonetheless, all Sap-inhibitory effects of lysozyme occurred at physiologically achievable levels of lysozyme [9].

It is of interest to speculate on the mechanisms by which lysozyme exerts its fungistatic or fungicidal properties. Fungi do not possess the peptidoglycan of the bacterial cell wall which is hydrolysed by lysozyme, but this enzyme also hydrolyses the $\beta-1,4$ linkages in chito-oligosaccharides [22]. This suggests that the effects of lysozyme on cell viability and morphology documented in this study may be due to the hydrolysis of chitin filaments which are present especially around the birth and bud scars and, to a lesser extent, in the lateral wall of C. albicans. Also, it was confirmed that the lysozyme had no detectable direct effect on BSA degradation under the conditions tested, as evidenced by silver-stain SDS-PAGE (data not shown). Certainly, the observed effect of lysozyme on Sap enzyme activity should reduce the ability of $C$. albicans to break down complex extracellular proteins as carbon or nitrogen sources, or both, and would thereby inhibit the yeast's capacity to invade tissues.

Lysozyme may also exert effects in other ways. The extrememly high cationic charge of lysozyme may allow it to bind avidly to yeast cell-wall mannans and thereby influence yeast viability in some as yet unknown manner [23]. Another mechanism may be produced by the interaction of lysozyme with other non-substrate fungal components and consequent damage to the cell membrane with resultant interference with ion transfer and de-regulation of influx and efflux of cellular constituents [11]. This could possibly account for current scanning electron microscopy findings showing both ballooned and deflated cells. Alternatively, lysozyme may exert its effect by activation or de-regulation of autolytic enzymes, as lysozyme receptors on yeast cell walls may be important in the regulation of autolysin formation [23].

Previous studies have suggested that $C$. albicans virulence is multifaceted and that its proteinases constitute some of its more important pathogenic features [24]. The characteristics of a single purified Sap (probably Sap2) of $C$. albicans have been studied extensively [25]. The findings of Wu et al. [26] and the data from Angiolella et al. [16] indicate that the secretion of Sap from antifungal drug-sensitive $C$. albicans strains is inhibited by antimycotics and also by saliva [13]. The present results also demonstrate that lysozyme, an intrinsic, non-specific salivary immune factor, has the ability not only to kill the yeast at higher concentrations but also to decrease $C$. albicans extracellular Sap activity and concentration at sublethal doses. It is noteworthy that lysozyme decreases the extracellular Sap activity approximately two-fold and extracellular immuno-detectable Sap concentration at least four-fold, without any negative effect on growth. It is not known why extracellular Sap concentration is more greatly affected by lysozyme than Sap activity, but one possible explanation could be that lysozyme treatment alters the antigenic sites recognised by the anti-Sap antibodies used to detect Sap concentration. However, this is unlikely as intracellular Sap concentration - also detected with the same anti-Sap antibody - increased with lysozyme treatment.

As far as we know, this is the first report of the inhibitory effect of lysozyme on C. albicans Sap activity and concentration. In general, variability in the effect of lysozyme on Sap activity and concentration was observed among $C$. albicans strains, although all strains demonstrated a $43-\mathrm{kDa}$ band in Western blots. The variable expression of Sap iso-enzymes by the strains tested could be due to the distinctively different reactions to lysozyme by the individual strains, as shown in similar studies [5]. Furthermore, heat- 
inactivated lysozyme had no adverse effect on Sap concentration or activity.

Monitoring the culture $\mathrm{pH}$ during a $60-\mathrm{h}$ incubation period indicated that lysozyme, despite its high cationic charge, did not significantly affect the $\mathrm{pH}$ of the YCBBSA medium; therefore, lysozyme was not reducing extracellular Sap activity or concentration by altering culture $\mathrm{pH}$. In contrast, treatment of $C$. albicans cells with lysozyme did inhibit the characteristic drop in culture $\mathrm{pH}$ associated with Sap production.

The mechanism of $C$. albicans Sap secretion into the extracellular environment is thought to be similar to that of other secreted proteins $[27,28]$. The data from the current study suggest that the adverse effects of lysozyme may be on the cell membrane, thereby hampering the Sap secretory process and leading to its intracellular accumulation. Furthermore, low levels of extracellular Sap may also stimulate the transcription and translation of $S A P$ genes, and induce consequent accumulation of intracellular Sap or Sap precursor proteins. It has been shown that Sap proteolytic activity is inducible and that expression of $S A P$ genes and processing of proteins may involve Kex 2 or similar activating proteins [29]. Therefore, one hypothesis could be that lysozyme down-regulates such activating proteins as a part of its mechanism of action on Sap activity.

It is also notable that the intracellular Sap and its precursor proteins, which increased due to the presence of lysozyme in the culture medium, were devoid of enzyme activity. One reason for this may be that lytic enzymes such as proteinase are normally produced as inactive precursors and are active only after intracellular processing and cleavage of a proregion from a larger prepropeptide [30]. The higher $M_{r}$ observed for the immunoreactive intracellular proteins in Western blots probed with anti-Sap antibodies support this theory. However, extracellular enzyme activity continued to increase with time, even though cell viability declined regardless of whether cells were grown in the presence or absence of lysozyme. As protein secretion generally is an active, energy-requiring process, cleavage of an inactive Sap precursor to form an active molecule also requires energy. Thus, it is not clear why enzyme activity should continue to increase despite reduced cell growth. Alternatively, this may be a cumulative effect of continuously secreting cells.

It is believed that several extracellular Sap iso-enzymes with distinctly different mol.wts can be induced in vitro in different strains of $C$. albicans strains. For example, with a Sap-inducing system different from that used in the present study, Morrison et al. [5] described a Sap iso-enzyme of $41 \mathrm{kDa}$ as well as Saps of $47-48 \mathrm{kDa}$. The $47-48-\mathrm{kDa}$ Saps are believed to be analogous to Sap2, which can appear as a doublet [5], and the $41-\mathrm{kDa}$ Sap has been speculated to be Sap8
[7]. Subsequently, by using the same Sap-inducing media as that used in the present study, White et al. [6] found that Sap2 $(43 \mathrm{kDa})$ was secreted by some clinical C. albicans strains, whereas, Sap1 and Sap3 (40 and $41 \mathrm{kDa}$ respectively) were also observed in Western blots of another strain (WO-1). The present studies further confirm the differential expression of Sap isoenzymes depending upon the strains studied.

Mature secreted Sap2 consists of 342 residues and has a calcuated $M_{r}$ of $35 \mathrm{kDa}$, but the apparent mol.wt in SDS-PAGE has been reported variously as $42-48 \mathrm{kDa}$ $[5,31]$. Furthermore, the open reading frames of the Sap iso-enzymes encode pre-proproteins which are processed during secretion [28]. This could account for the $45-\mathrm{kDa}$ species detected in the present study. Previous studies have also shown that autodegradation of Sap produces major bands of $c .20 \mathrm{kDa}$ in cell extracts [32], which are similar in $M_{r}$ to two protein bands in the current study $(20 \mathrm{kDa}$ and $17 \mathrm{kDa})$. A prominent band was also obtained at $42 \mathrm{kDa}$, which, in the strain tested (BM20617), may represent some degradation of the $45-\mathrm{kDa}$ precursor proteins. It is not known if other strains, which demonstrated extracellular Sap iso-enzymes at $41 \mathrm{kDa}$, would have additional intracellular bands relative to the strain tested (BM20617). The nature of the immunoreactive band at $65 \mathrm{kDa}$ in the extracts from the lysozymetreated cells in the current study is uncertain, but one explanation for this band may be that there are intracellular aspartyl proteinases which may be upregulated by the presence of lysozyme. It has been shown that an intracellular aspartyl proteinase of $60 \mathrm{kDa}$ exists [33], and this proteinase may share immunoactive epitopes with Sap2.

In-vivo oral concentrations of lysozyme range from 1 to $20 \mu \mathrm{g} / \mathrm{ml}$ [9], and hence concentrations tested in this study could be achieved easily in vivo. Furthermore, the salivary concentrations of lysozyme is elevated up to five-fold in HIV-infected individuals $[34,35]$, and the oral carriage of Candida approximates $80-100 \%$ in such cohorts [2]. Also, oral isolates of $C$. albicans from HIV-infected individuals exhibit significantly greater in-vitro proteolytic activity than isolates from healthy individuals [26]. One explanation for these findings may be the high prevalence of lysozymeresistant $C$. albicans isolates in HIV-infected individuals and studies are currently being performed to confirm this hypotheses.

In conclusion, the current data have shown that lysozyme, a potent non-specific defence factor in human mucosal secretions, has at least a bimodal action on C. albicans species - killing the organism at higher doses, and affecting Sap concentration and activity at lower doses.

We gratefully acknowledge the financial support from the Research Grants Council of Hong Kong. T. W. was employed as a Research 
Assistant during this Project with CRCG funds from the University of Hong Kong, Hong Kong.

\section{References}

1. Holmstrup P, Samaranayake LP. Acute and AIDS-related oral candidoses. In: Samaranayake LP, MacFarlane TW (eds) Ora candidosis. London, Wright. 1990; 133-155.

2. Samaranayake LP. Oral mycoses in HIV infection. Oral Surg Oral Med Oral Pathol 1992; 73: 171-180.

3. Hube B, Sanglard D, Odds FC et al. Disruption of each of the secreted aspartyl proteinase genes $S A P 1, S A P 2$, and $S A P 3$ of Candida albicans attenuates virulence. Infect Immun 1997; 65: 3529-3538.

4. Sanglard D, Hube B, Monod M, Odds FC, Gow NAR. A triple deletion of the secreted aspartyl proteinase genes SAP4, SAP5, and SAP6 of Candida albicans causes attenuated virulence. Infect Immun 1997; 65: 3539-3546.

5. Morrison CJ, Hurst SF, Bragg SL et al. Heterogeneity of the purified extracellular aspartyl proteinase from Candida albicans: characterization with monoclonal antibodies and $\mathrm{N}$ terminal amino acid sequence analysis. Infect Immun 1993; 61 2030-2036.

6. White TC, Miyasaki SH, Agabian N. Three distinct secreted aspartyl proteinases in Candida albicans. J Bacteriol 1993 175: $6126-6133$

7. Monod M, Togni G, Hube B, Sanglard D. Multiplicity of genes encoding secreted aspartic proteinase in Candida species. Mol Microb 1994; 13: 357-368.

8. White TC, Agabian N. Candida albicans secreted aspartyl proteinase: isoenzyme pattern is determined by cell type, and levels are determined by environmental factors. $J$ Bacteriol 1995; 177: 5215-5221.

9. Tenovuo J, Lumikari M, Soukka T. Salivary lysozyme, lactoferrin and peroxidases: antibacterial effects on cariogenic bacteria and clinical applications in preventive dentistry. Proc Finn Dent Soc 1991; 87: 197-208.

10. Ruechel R. Virulence factors of Candida species. In: Samaranayake LP, MacFarlane TW (eds) Oral candidosis London, Wright. 1990: 47-65.

11. Tobgi ST, Samaranayake LP, MacFarlane TW. The in vitro susceptibility of Candida species to lysozyme. Oral Microbiol Immunol 1987; 2: 1-4.

12. Samaranayake YH, MacFarlane TW, Samaranayake LP, Aitchison $T$. The in vitro proteolytic and saccharolytic activity of Candida species cultured in human saliva. Oral Microbiol Immunol 1994; 9: 229-235.

13. Germaine GR, Tellefson LM. Effect of $\mathrm{pH}$ and human saliva on proteinase production by Candida albicans. Infect Immun 1981; 31: 323-326.

14. Samaranayake LP, Hughes A, MacFarlane TW. The proteolytic potential of Candida albicans in human saliva supplemented with glucose. J Med Microbiol 1984; 17: 13-22.

15. Mackenzie DWR. Serum tube identification of Candida albicans. J Clin Pathol 1962; 15: 563-565.
16. Angiolella L, De Bernardis F, Bromuro C, Mondello F, Ceddia T, Cassone A. The effect of antimycotics on secretory acid proteinase of Candida albicans. J Chemother 1990; 2: 55-61.

17. De Bernardis F, Agatensi L, Ross IK et al. Evidence for a role for secreted aspartate proteinase of Candida albicans in vulvovaginal candidiasis. J Infect Dis 1990; 161: 1276-1283.

18. Kwong-Chung KJ, Lehman D, Good C, Magee PT. Genetic evidence for role of extracellular proteinase in virulence of Candida albicans. Infect Immun 1985; 49: 571-575.

19. Sprott GD, Koval SF, Schnaitman CA. Cell fractionation. In: Gerhardt P, Murray RGE, Wood WA, Krieg NR (eds) Methods for general molecular bacteriology. Washington, DC, American Society for Microbiology. 1994: 72-103.

20. Kamaya T. Lytic action of lysozyme on Candida albicans. Mycopathol Mycol Appl 1970; 42: 197-207.

21. Marquis G, Montplaisir S, Garzon S, Strykowski H, Auger D. Fungitoxicity of muramidase. Ultrastructural damage to Candida albicans. Lab Invest 1982; 46: 627-636.

22. Imoto $T$, Johnson LN, North ACT, Philips DC, Rupler JA. Vertebrate lysozymes. In: Boyer PD (ed) The enzymes, 3rd edn. New York, Academic Press. 1972: 665-868.

23. Petit JF, Jollès P. Purification and analysis of human saliva lysozyme. Nature 1963; 200: 168-169.

24. Culter JE. Putative virulence factors of Candida albicans. Annu Rev Microbiol 1991; 45: 187-218.

25. Rüchel R. Properties of a purified proteinase from the yeast Candida albicans. Biochim Biophys Acta 1981; 659: 99-113.

26. Wu T, Samaranayake LP, Cao BY, Wang J. In-vitro proteinase production by oral Candida albicans isolates from individuals with and without HIV infection and its attenuation by antimycotic agents. $J$ Med Microbiol 1996; 44: 311-316.

27. Burgess TL, Kelly RB. Constitutive and regulated secretion of proteins. Annu Rev Cell Biol 1987; 3: 243-249.

28. Homma M, Kanbe T, Chibana H, Tanaka K. Detection of intracellular forms of secretory aspartic proteinase in Candida albicans. J Gen Microbiol 1992; 138: 627-633.

29. Newport G, Agabian N. KEX2 influences Candida albicans proteinase secretion and hyphal formation. J Biol Chem 1997, 272: 28954-28961

30 Mechler B, Müller M, Müller H, Meussdoerffer F, Wolf DH. In vivo biosynthesis of the vacuolar proteinase $\mathrm{A}$ and $\mathrm{B}$ in the yeast Saccharomyces cerevisiae. $J$ Biol Chem 1982; 257: $11203-11206$

31. Wright RJ, Carne A, Hieber AD, Lamont IL, Emerson GW, Sullivan PA. A second gene for a secreted aspartic proteinase in Candida albicans. $J$ Bacteriol 1992; 174: 7848-7853.

32. Cutfield S, Marshall C, Moody P, Sullivian P, Cutfield J. Crystallization of inhibited aspartic proteinase from Candida albicans. J Mol Biol 1993; 234: 1266-1269.

33. Portillo F, Gancedo C. Purification and properties of three intracellular proteinases from Candida albicans. Biochim Biophys Acta 1986; 881: 229-235.

34. Atkinson JC, Yeh C, Oppenheim FG, Bermudez D, Baum BJ, Fox PC. Elevation of salivary antimicrobial proteins following HIV-1 infection. J Acquir Immune Defic Syndr 1990; 3: 41-48.

35. Mandel ID, Barr CE, Turgeon L. Longitudinal study of parotid saliva in HIV-1 infection. J Oral Pathol Med 1992; 21: 209-213. 